\title{
Hubungan Usia Penyandang Diabetes Melitus Tipe 2 dan Disfungsi Ereksi
}

\author{
${ }^{1}$ Rian Panelewen \\ ${ }^{2}$ Janette M. Rumbajan \\ ${ }^{2}$ Lusiana Satiawati
}

\author{
${ }^{1}$ Program Studi Pendidikan Dokter Fakultas Kedokteran Universitas Sam Ratulangi Manado \\ ${ }^{2}$ Bagian Biologi Fakultas Kedokteran Universitas Sam Ratulangi Manado \\ Email: rian.panelewen95@gmail.com
}

\begin{abstract}
Diabetes mellitus (DM) is a disease with high blood glucose level due to the inadequasy of insulin. Erectile dysfunction or inability to maintain an erection often occurs among males due to various factors. Males with DM have higher risk of erectile dysfunction compared to those without DM. This study was aimed to determine the relationship of the age of type 2 diabetes mellitus (T2DM) patient and erectile dysfunction. This was an analytical survey study with a cross sectional design. Respondents were all patients with T2DM at the Endocrine Polyclinic of Prof. Dr. R. D. Kandou Hospital Manado from October 2015 to January 2016. There were 38 respondents in this study; most had mild erectile dysfunction $(36.8 \%)$. The Chi-square analysis showed a significant relationship $(\mathrm{p}<0.05)$ between the age of T2DM patients and erectile dysfunction. Conclusion: There was a significant relationship between the age of T2DM patients and erectile dysfunction. The older the patient, the more severe the erectile dysfunction.
\end{abstract}

Keywords: diabetes mellitus, erectile dysfunction

\begin{abstract}
Abstrak: Diabetes melitus (DM) adalah penyakit dimana kadar glukosa dalam darah tinggi karena tubuh tidak dapat melepaskan atau menggunakan insulin secara adekuat. Disfungsi ereksi (DE) atau ketidakmampuan mempertahankan ereksi seringkali dialami oleh pria karena berbagai faktor. Laki-laki yang menyandang DM berisiko DE lebih tinggi dibandingkan dengan yang tidak menyandang DM. Penelitian ini bertujuan untuk mengetahui hubungan usia penyandang DMT2 dan tingkat DE. Jenis penelitian ialah survei analitik dengan desain potong lintang. Responden penelitian ialah semua pasien DMT2 di Poliklinik Endokrin periode Oktober 2015-Januari 2016. Hasil penelitian mendapatkan dari 38 responden, terbanyak yang mengalami DE ringan (36,8\%). Berdasarkan analisis chi-square didapatkan hubungan bermakna $(p<0,05)$ antara usia penyandang DMT2 dan DE. Simpulan: Terdapat hubungan bermakna antara usia penyandang DMT2 dan disfungsi ereksi. Semakin tinggi usia, semakin parah tingkat disfungsi ereksi yang terjadi.
\end{abstract}

Kata kunci: diabetes mellitus, disfungsi ereksi

Diabetes melitus (DM) adalah penyakit dimana kadar glukosa dalam darah tinggi karena tubuh tidak dapat melepaskan atau menggunakan insulin secara adekuat. Kadar glukosa darah sepanjang hari bervariasi, meningkat setelah makan dan kembali normal dalam waktu 2 jam. Kadar glukosa darah normal pada pagi hari setelah malam sebelumnya berpuasa ialah
70-110 mg/dL. Kadar glukosa darah biasanya kurang dari 120-140 mg/dL pada 2 jam setelah makan atau minum cairan mengandung gula maupun karbohidrat lainnya. ${ }^{1}$

Provinsi Sulawesi Utara merupakan salah satu provinsi yang mempunyai prevalensi DM yang cukup tinggi. Menurut Riset Kesehatan Dasar (Riskesdas) tahun 
2007, prevalensi penyakit DM di Sulawesi Utara berada pada peringkat keenam yaitu sebesar $8,1 \%$. Hal ini menunjukkan tingginya prevalensi penyakit DM di Sulawesi Utara jika dibandingkan dengan prevalensi nasional DM yang hanya sebesar $5,7 \% .^{2}$

Disfungsi ereksi (DE) atau ketidakmampuan mempertahankan ereksi seringkali dialami oleh pria karena berbagai faktor. Menurut National Institutes of Health (NIH), sekitar $4 \%$ dari pria berusia 50 tahun telah mengalami DE, dan hampir $50 \%$ dari pria berusia 75 tahun pun mengalami hal serupa. ${ }^{1}$

Disfungsi ereksi dapat disebabkan berbagai faktor yaitu faktor yang bersifat organik (ketuaan atau penyakit di dalam tubuh) atau faktor yang bersifat nonorganik (psikologis, obat-obatan, rokok, dan lain-lain). Disfungsi ereksi organik biasanya terjadi pada orang tua dan jarang terjadi pada pria berusia <40 tahun. ${ }^{1}$ Bagi pria, kesulitan mendapatkan dan mempertahankan ereksi merupakan tanda-tanda awal penyakit DM. ${ }^{3}$

Faktor usia dan adanya penyakit DM masing-masing merupakan faktor risiko DE. Penelitian ini bertujuan untuk mengetahui hubungan antara usia penyandang diabetes melitus tipe 2 (DMT2) dan DE.

\section{METODE PENELITIAN}

Jenis penelitian ini ialah survei analitik dengan desain potong lintang pada pasien DMT2 di Poliklinik Endokrin RSUP Prof. Dr. R. D. Kandou Manado. Responden penelitian ini ialah semua pasien DMT2 di Poliklinik Endokrin periode Oktober 2015 - Januari 2016. Variabel penelitian yang diteliti yaitu: usia dan disfungsi ereksi.

\section{HASIL PENELITIAN}

Penelitian ini dilakukan di Poliklinik Endokrin RSUP Prof. Dr. R. D. Kandou Manado dan didapatkan 38 responden. Distribusi responden terhadap kelompok usia memperlihatkan responden terbanyak pada kelompok usia 51-55 tahun (36,8\%), diikuti oleh kelompok usia 46-50 tahun $(28,9 \%)$, dan kelompok usia 41-45 tahun $(18,4 \%)$ (Tabel 1).
Tabel 1. Distribusi responden terhadap kelompok usia

\begin{tabular}{ccc}
\hline \multirow{2}{*}{ Usia } & \multicolumn{2}{c}{ Responden } \\
\cline { 2 - 3 } & $\mathbf{N}$ & $\mathbf{\%}$ \\
\hline 35-40 tahun & 1 & 2,7 \\
41-45 tahun & 7 & 18,4 \\
46-50 tahun & 11 & 28,9 \\
51-55 tahun & 14 & 36,8 \\
56-60 tahun & 3 & 7,9 \\
$>$ 60 tahun & 2 & 5,3 \\
\hline
\end{tabular}

Tabel 2 memperlihatkan distribusi responden terhadap seringnya ereksi. Persentase tertinggi terdapat pada 'kadangkadang' (55,3\%) diikuti oleh 'sesekali' $(15,8 \%)$ dan 'tidak pernah atau hampir tidak pernah' $(13,1 \%)$.

Tabel 2. Distribusi responden terhadap seringnya ereksi

\begin{tabular}{ccc}
\hline Ereksi & \multicolumn{2}{c}{ Responden } \\
\cline { 2 - 3 } & $\mathbf{N}$ & $\mathbf{\%}$ \\
\hline Selalu atau hampir selalu & 0 & 0 \\
Sering $(>50 \%)$ & 3 & 7,9 \\
Kadang-kadang $(50 \%)$ & 21 & 55,3 \\
Sesekali $(<50 \%)$ & 6 & 15,8 \\
Tidak pernah atau hampir & 5 & 13,1 \\
tidak pernah & & \\
Tidak melakukan aktivitas & 3 & 7,9 \\
seksual & & \\
\hline
\end{tabular}

Tabel 3 memperlihatkan distribusi responden terhadap seringnya ereksi cukup keras untuk penetrasi. Persentase tertinggi terdapat pada 'kadang-kadang' (50\%) sebesar 31,6\%, 'sesekali' (<50\%) sebesar $28,9 \%$, dan 'sering' ( $>50 \%$ ) sebesar $15,8 \%$.

Tabel 3. Distribusi responden terhadap seringnya ereksi cukup keras untuk penetrasi

\begin{tabular}{ccc}
\hline Ereksi & \multicolumn{2}{c}{ Responden } \\
\cline { 2 - 3 } & $\mathbf{N}$ & $\mathbf{\%}$ \\
\hline Selalu atau hampir selalu & 1 & 2,7 \\
Sering $(>50 \%)$ & 6 & 15,8 \\
Kadang-kadang $(50 \%)$ & 12 & 31,6 \\
Sesekali $(<50 \%)$ & 11 & 28,9 \\
Tidak pernah atau 2amper & 5 & 13,1 \\
tidak pernah & & \\
Tidak melakukan & 3 & 7,9 \\
perangsangan seksual & & \\
\hline
\end{tabular}

Tabel 4 memperlihatkan distribusi 
responden terhadap seringnya penetrasi. Persentase tertinggi terdapat pada 'kadangkadang' (50\%)' sebesar 31,6\%, 'sering' (50\%)' sebesar 26,3\%, dan 'tidak pernah atau hampir tidak pernah' sebesar $15,8 \%$.

Tabel 4. Distribusi responden terhadap seringnya penetrasi

\begin{tabular}{ccc}
\hline Ereksi & \multicolumn{2}{c}{ Responden } \\
\cline { 2 - 3 } & $\mathbf{N}$ & $\mathbf{\%}$ \\
\hline Selalu atau hampir selalu & 2 & 5,3 \\
Sering $(>50 \%)$ & 10 & 26,3 \\
Kadang-kadang $(50 \%)$ & 12 & 31,6 \\
Sesekali $(<50 \%)$ & 5 & 13,1 \\
Tidak pernah atau hampir & 6 & 15,8 \\
tidak pernah & & \\
Tidak melakukan aktivitas & 3 & 7,9 \\
seksual & & \\
\hline
\end{tabular}

Tabel 5 memperlihatkan distribusi responden terhadap seringnya tetap ereksi setelah penetrasi. Persentase tertinggi ialah 'kadang-kadang' dan 'sesekali', masingmasing $28,9 \%$, dan 'tidak pernah atau hampir tidak pernah' sebesar $18,4 \%$.

Tabel 5. Distribusi responden terhadap lamanya ereksi

\begin{tabular}{ccc}
\hline Ereksi & \multicolumn{2}{c}{ Responden } \\
\cline { 2 - 3 } & $\mathbf{N}$ & $\mathbf{\%}$ \\
\hline Selalu atau hampir selalu & 2 & 5,3 \\
Sering $(>50 \%)$ & 4 & 10,6 \\
Kadang-kadang $(50 \%)$ & 11 & 28,9 \\
Sesekali $(<50 \%)$ & 11 & 28,9 \\
Tidak pernah atau hampir & 7 & 18,4 \\
tidak pernah & & \\
Tidak melakukan & 3 & 7,9 \\
aktivitas seksual & & \\
\hline
\end{tabular}

Tabel 6 memperlihatkan distribusi responden terhadap kesulitan mempertahankan ereksi sampai selesai hubungan kelamin. Persentase tertinggi terdapat pada 'sedikit sulit' sebesar 36,8\%, 'sulit' 15,8\%, dan 'tidak sulit' dan 'sangat sulit' masingmasing $10,6 \%$.

Tabel 7 memperlihatkan distribusi responden terhadap keyakinan dapat ereksi dan bertahan. Persentase tertinggi terdapat pada 'cukup' sebesar 52,6\%, 'rendah' $23,6 \%$, dan 'sangat rendah' $15,8 \%$.
Tabel 6. Distribusi responden terhadap kesulitan mempertahankan ereksi sampai selesai hubungan kelamin

\begin{tabular}{ccc}
\hline \multirow{2}{*}{ Ereksi } & \multicolumn{2}{c}{ Responden } \\
\cline { 2 - 3 } & $\mathbf{N}$ & $\mathbf{\%}$ \\
\hline Tidak sulit & 4 & 10,6 \\
Sedikit sulit & 14 & 36,8 \\
Sulit & 6 & 15,8 \\
Sangat sulit & 4 & 10,6 \\
Sangat sulit sekali & 7 & 18,4 \\
Tidak melakukan & 3 & 7,9 \\
aktivitas seksual & & \\
\hline
\end{tabular}

Tabel 7. Distribusi responden terhadap keyakinan dapat ereksi dan bertahan

\begin{tabular}{ccc}
\hline \multirow{2}{*}{ Ereksi } & \multicolumn{2}{c}{ Responden } \\
\cline { 2 - 3 } & $\mathbf{N}$ & $\mathbf{\%}$ \\
\hline Sangat tinggi & 2 & 5,3 \\
Tinggi & 1 & 2,7 \\
Cukup & 20 & 52,6 \\
Rendah & 9 & 23,6 \\
Sangat rendah & 6 & 15,8 \\
\hline
\end{tabular}

Tabel 8 memperlihatkan distribusi usia responden terhadap DE. Didapatkan responden usia 35-40 tahun yang tidak disfungsi sebanyak 2 orang (2,7\%), disfungsi ringan tidak ada $(0 \%)$, disfungsi sedang-ringan tidak ada (0\%), disfungsi sedang tidak ada $(0 \%)$, dan berat tidak ada (0\%). Pada usia 41-45 didapatkan responden yang tidak disfungsi tidak ada $(0 \%)$, disfungsi ringan 5 orang $(13,1 \%)$, disfungsi sedang-ringan 2 orang $(5,3 \%)$, disfungsi sedang tidak ada $(0 \%)$, dan disfungsi berat tidak ada (0\%). Pada usia 46-50 tahun didapatkan responden yang tidak disfungsi tidak ada $(0 \%)$, disfungsi ringan 6 orang $(15,8 \%)$, disfungsi sedang-ringan 4 orang $(10,6 \%)$, disfungsi sedang 1 orang $(2,7 \%)$, dan disfungsi berat tidak ada $(0 \%)$. Pada usia 51-55 tahun didapatkan responden yang tidak disfungsi sebanyak 2 orang (5,3\%), disfungsi ringan 2 orang (5,3\%), disfungsi sedang-ringan 4 orang $(10,6 \%)$, disfungsi sedang 3 orang $(7,9 \%)$, dan disfungsi berat 3 orang $(7,9 \%)$. Pada usia 56-60 tahun didapatkan responden yang tidak disfungsi tidak ada (0\%), disfungsi ringan 1 orang $(2,7 \%)$, disfungsi sedangringan tidak ada $(0 \%)$, disfungsi sedang 2 
orang $(5,3 \%)$, dan disfungsi berat tidak ada (0\%). Pada usia >60 tahun didapatkan responden yang tidak disfungsi tidak ada $(0 \%)$, disfungsi ringan tidak ada $(0 \%)$, disfungsi sedang-ringan tidak ada (0\%), disfungsi sedang 1 orang $(2,7 \%)$, dan disfungsi berat 1 orang $(2,7 \%)$. Berdasarkan analisis chi-square hubungan usia penyandang DMT2 terhadap disfungsi ereksi didapatkan nilai kemaknaan $\mathrm{p}<0,05$.

Tabel 8. Distribusi usia responden terhadap disfungsi ereksi

\begin{tabular}{cccccc}
\hline Usia & \multicolumn{5}{c}{ Disfungsi ereksi } \\
\cline { 2 - 6 } & Normal & Ringan & $\begin{array}{c}\text { Sedang- } \\
\text { Ringan }\end{array}$ & Sedang & Berat \\
\hline 35-40 tahun & $2,7 \%$ & 0 & 0 & 0 & 0 \\
41-45 tahun & 0 & $13,1 \%$ & 5,3 & 0 & 0 \\
46-50 tahun & 0 & $15,8 \%$ & 10,6 & $2,7 \%$ & 0 \\
$51-55$ tahun & $5,3 \%$ & $5,3 \%$ & 10,6 & $7,9 \%$ & $7,9 \%$ \\
56-60 tahun & 0 & $2,7 \%$ & 0 & $5,3 \%$ & 0 \\
$>60$ tahun & 0 & 0 & 0 & $2,7 \%$ & $2,7 \%$ \\
\hline
\end{tabular}

\section{BAHASAN}

Diabetes melitus merupakan penyakit yang dapat disebabkan oleh pola makan. Pola makan masyarakat Sulawesi Utara yang tinggi kalori merupakan salah satu faktor risiko dari penyakit DM ini. Prevalensi penyakit DM di Sulawesi Utara berada pada tingkat keenam yaitu sebesar $8,1 \%$ dibandingkan prevalensi nasional DM yang sebesar $5,7 \% .^{2}$ Diabetes melitus merupakan salah satu faktor risiko terjadinya DE. Demikian juga dengan faktor usia. Semakin tinggi usia seorang pria maka semakin tinggi pula kemung-kinan pria tersebut mengalami disfungsi ereksi. Faktor DM maupun faktor usia masing-masing meningkatkan kemungkinan DE. Penelitian ini mengonfirmasi adanya hubungan usia penyandang DM dan DE pada pasien rawat jalan di Poliklinik Endokrin RSUP Prof. Dr. R. D. Kandou Manado dengan nilai kemaknaan yang sangat bermakna ( $p$ $<0,05)$.

Disfungsi ereksi adalah salah satu komplikasi mikrovaskuler dari DM akibat peningkatan kadar gula darah yang dapat menyebabkan kerusakan pembuluh darah yang mengalir ke penis. ${ }^{4}$ Disfungsi ereksi ini dievaluasi dengan menggunakan kuesioner IIEF-5 yang terdiri atas 6 pertanyaan. Hasil skor kuesioner IIEF-5 ini dikelompokkan menjadi disfungsi berat $(0$ 6), disfungsi sedang (7-12), disfungsi ringan-sedang (13-18), disfungsi ringan (19-24), serta tidak ada disfungsi (25-30). ${ }^{5}$

Pada 38 responden yang memenuhi kriteria inklusi dan eksklusi dari penelitian ini, didapatkan distribusi responden berdasarkan usia terbanyak pada kelompok usia 51-55 tahun (36,8\%). Dari 14 responden di kelompok usia tersebut berdasarkan kuesioner IIEF-5 didapatkan 12 responden yang mengalami DE, sedangkan 2 responden lainnya tidak mengalami DE.

Berdasarkan tingkat DE didapatkan 3 responden $(8 \%)$ yang tidak mengalami DE, sedangkan sisanya 35 responden $(92,1 \%)$ mengalami DE. Dari 35 responden $(92,1 \%)$ yang mengalami DE ini terdapat 14 responden $(36,8 \%)$ mengalami $\mathrm{DE}$ ringan, 10 responden $(26,3 \%)$ mengalami $\mathrm{DE}$ sedang-ringan, 7 responden $(18,4 \%)$ mengalami DE sedang, dan 4 responden $(10,5 \%)$ mengalami DE berat. Hasil ini menunjukkan bahwa pada penyandang DMT2 yang diteliti paling banyak yang mengalami DE ringan (36,8\%). Hasil ini sejalan dengan penelitian sebelumnya tentang pengaruh lamanya DMT2 terhadap terjadinya DE yang menyatakan bahwa DMT2 yang lama bisa mengakibatkan DE. ${ }^{6}$

Pada usia lanjut, DE rentan terjadi karena penurunan jumlah otot polos korpus kavernosum yang dibutuhkan untuk ereksi, kelainan atau penyakit yang berhubungan dengan penurunan kadar hormon testo- 
steron, juga akibat dari komplikasi penyakit seperti DMT2, dimana kadar gula yang terganggu dapat merusak pembuluh darah, termasuk pembuluh darah yang mengalir ke penis sehingga terjadi kerusakan saraf tepi. ${ }^{4,6}$

Berdasarkan analisis chi-square pada penelitian ini hubungan usia penyandang DMT2 terhadap DE didapatkan nilai kemaknaan $\mathrm{p}<0,05$ yang menunjukkan adanya hubungan bermakna antara usia penyandang DMT2 dan DE. Hal ini berarti semakin tinggi usia penyandang DM maka semakin tinggi pula tingkat DE yang terjadi.

\section{SIMPULAN}

Terdapat hubungan antara usia penyandang DMT2 dan disfungsi ereksi pada pria. Semakin tinggi usia semakin berat disfungsi ereksi yang terjadi.

Prevalensi usia penyandang DMT2 dengan disfungsi ereksi terbanyak pada kelompok usia 51-55 tahun.

\section{SARAN}

Diperlukan perhatian yang lebih, khususnya penentuan diagnosis dan penanganan disfungsi ereksi pada pria penyandang DMT2.

Perlu dilakukan edukasi terhadap penyandang DMT2 serta memperbaiki gaya hidup karena semakin bertambah usia maka semakin berat tingkat disfungsi ereksi yang dapat terjadi.

\section{DAFTAR PUSTAKA}

1. Irianto K. Memahami Berbagai Macam Penyakit. Bandung: Alfabeta, 2014.

2. Awad N, Langi YA, Pandelaki K. Gambaran faktor resiko pasien diabetes melitus tipe II di Poliklinik Endokrin Bagian/SMF FK-Unsrat di RSU Prof. Dr. R. D. Kandou Manado.periode Mei 2011-Oktober 2011. eBm. 2013;1(1)45-9.

3. Bivalacqua TJ, Usta MF, Champion HC, Kadowitz PJ, Hellstrom WJG. Endhotelial dysfunction in erectile dysfunction: role of the endothelium in erectile physiology and disease. $\mathbf{J}$ Androl. 2003;24(6Suppl):S17-37.

4. Suyono S. Diabetes melitus di Indonesia. In: Sudoyo AW, Setiohadi B, Alwi I, Simadibrata MK, Setiati S, editors. Buku Ajar Ilmu Penyakit Dalam. Jilid III. Jakarta: InternaPublishing, 2009; p. $1877-80$

5. Rosen RC, Riley A, Wagner G, Osterloh IH, Kirkpatrick J, Mishra A. The international index of erectile function (IIEF): a multidimensional scale for assessment of erectile dysfunction. Urology. 1997;49:822-30.

6. Perkumpulan Endokrinologi Indonesia. Konsensus Pengelolaan dan Pencegahan Diabetes Melitus di Indonesia. Jakarta: PB PERKENI, 2011. 